\title{
Ruptured Distal Posterior Cerebral Artery Aneurysm Presenting with Massive Intraventricular Hemorrhage
}

\author{
-Case Report-
}

\author{
Kenji KIKUchi, M.D., Kazuo Watanabe, M.D., ${ }^{*}$ \\ and Masayoshi Kowada, M.D.
}

\section{脳室内出血を伴った破裂後大脳動脈末梢部動脈瘤の 1 例}

\author{
菊 地 顕 次, 渡 辺 一 夫, 古和田 正悦 \\ 秋田大学 脳神経外科, *南東北病院 脳神経外科
}

要 旨: 後大脳動脈末梢部, とりわけ $\mathrm{P}_{3}$ portion 以降の動脈瘤はまれで, 動脈瘤全体の $0.3 \%$ 占 めるにすぎない，手術方法は動脈溜の部位や大きさによって異なるが，大別すると pterional, subtemporal, temporooccipital 掞よび occipital approach な゙が報告されている. 最近経験した後大脳動 脈末梢部動脈瘤の急性期手術例を報告し，手術アプローチ拈よび合併する脳室内出血について若干の 文献的考察を行った。

症例は突然の頭痛，嘔吐㧍よび意識障害で発症した 62 歳の女性で，CT でシルヴィウス溝や脳底 槽のクモ膜下出血の所見のほかに, 左側脳室後角近傍の脳実質内出血に連続し脳坴内出血が描出され た．脳血管撮影では左後大脳動脈末梢の parieto-occipital artery から外上方に突出する, 最大径 8 $\mathrm{mm}$ の囊状動脈瘤が造影された，手術は腹卧位で脳室ドレナージ後に左後頭開頭を行った，後頭極を テントより压排・挙上して四丘体槽に到達し, 最初に後大脳動脈近位部を確保して脳内血腫を除去し たのち，後大脳動脈を順行性に辿って動脈瘤を確認してクリップした。このoccipital supratentorial approach は $\mathrm{P}_{3}$ 以降の後大脳動脈末梢部動脈瘤に対して十分な視野が得られ有用であった。

Summary : The authors report a rare case of distal posterior cerebral artery (PCA) aneurysm in a 62-year-old woman presenting with both subarachnoid and intraventricular hemorrhages. The saccular aneurysm arose from the parieto-occipital artery of the PCA projecting laterally. With the patient placed in a prone position the aneurysm was approached by a supratentorial route through an occipital craniotomy, and successfully obliterated with a Sugita's clip. The patient's postoperative course was uneventful without neurological deficits. The literature concerning aneurysms originating from the distal portion of the PCA is reviewed in the literature and the surgical approaches to the aneurysm are also discussed.

\section{Introduction}

Aneurysms of the posterior cerebral artery (PCA) are rare and estimated to comprise approximately $0.7-2.2 \%^{6) 11) 13)}$ of all intracranial aneurysms. The
Key words :

- aneurysm

- posterior cerebral artery

- intraventricular hemor. rhage

Neurosurgical Service, Akita University Hospital, Akita; *Department of Neurosurgery, Southern Tohoku Research Institute for Neuroscience, Kooriyama, Fukushima (Received January 30, 1992) [Address reprints request to: Kenji Kikuchi, M.D., Neurosurgical Service, Akita University Hospital, 1-1-1 Hondo, Akita, 010 Japan] 
Yasargil ${ }^{14)}$ described only 3 patients whose aneurysms arose from the quadrigeminal of $\mathrm{P}_{3}$ segment of the PCA in his series of 97 patients with vertebrobasilar aneurysms.

We describe an unusual case of ruptured saccular aneurysm of the distal PCA presenting with both extensive subarachnoid and intraventricular hemorrhages, which was successfully managed by an occipital supratentorial approach.

\section{Case Report}

A 62-year-old woman was transferred to the hospital after she suddenly developed severe occipital headaches and vomitings, followed by loss of conciousness.

On admission the patient was lethargic, though easily arousable, with stiffness of her neck. There were no obvious motor or sensory abnormalities and her reflexes were equal bilaterally in both upper and lower extremities. The neurological status was then evaluated as Hunt and Kosnik's grade 3. Physical examination, the hemogram, urinalysis and other chemical studies were found to be normal. Roentgenogram of the chest and electrocardiogram were interpreted as within normal limits.

A computed tomographic (CT) scan demonstrated a significant amount of blood clots present predominantly in the left lateral and the third ventricles as well as in the cerebral parenchyma adjacent to the left occipital horn. CT also revealed areas of high density within the subarachnoid cisterns prominently in the perimesencephalic cistern, consistent with the finding of subarachnoid hemorrhage (Fig. 1). Right retrograde brachial angiography showed a saccular aneurysm approximately $5 \times 8 \mathrm{~mm}$ in size arising from the parieto-occipital artery of the left PCA and projecting laterally and superiorly. There was no evidence of vasospasm on the adjacent blood vessles (Fig. 2).

The patient was operated upon the following day by the occipital supratentorial approach. The patient was placed in a prone position with the neck slightly anteflexed. After a ventriculostomy was done through a separate burr hole into the occipital horn of the right lateral ventricle, a generous left occipital craniotomy was performed. It extended medially to the sagittal sinus and inferiorly to the transverse sinus. The dural flap was hinged medially. The occipital lobe was then gently retracted superiorly from the tentorium, and by the occipital supratentorial approach the PCA

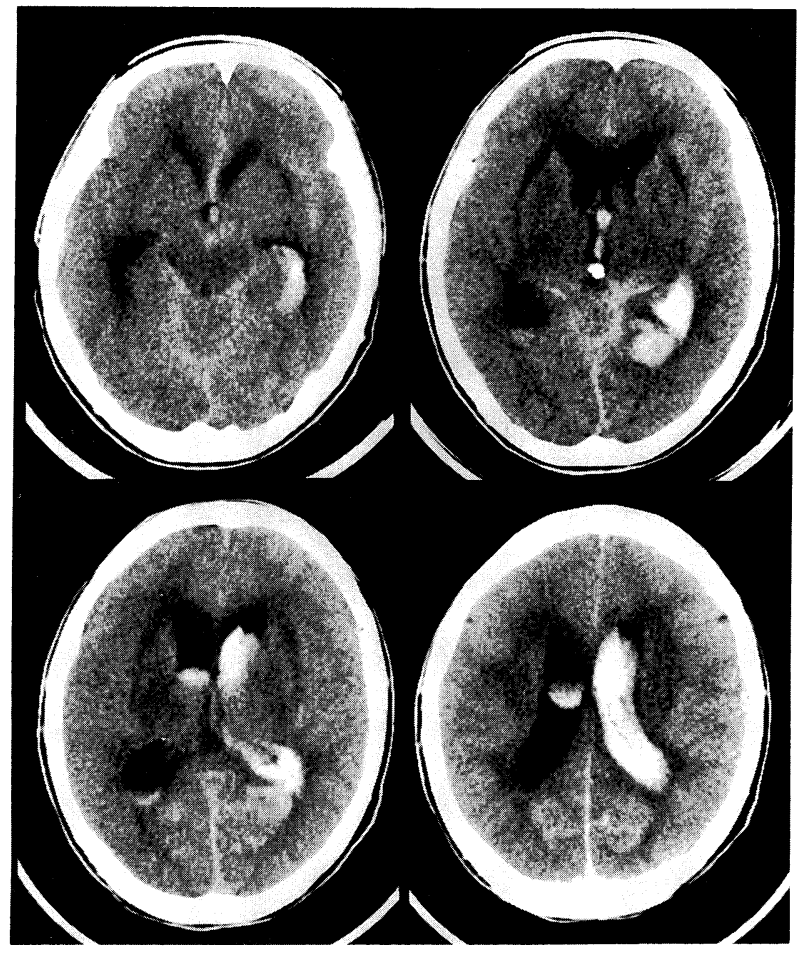

Fig. 1 Plain CT scans obtained before the operation, revealing subarachnoid and intraventricular hemorrhages. Intracerebral hematoma is also seen adjacent to the occipital horn of the left lateral ventricle.

proximal to the aneurysm was identified in the quadrigeminal cistern. When the PCA was followed distally with caution and adjacent intracerebral hematoma was removed, a saccular aneurysm was found pointing laterally. A small Sugita's straight clip was placed on the neck of the aneurysm. The postoperative course was uneventful and successful obliteration of the aneurysm was confirmed on the postoperative angiography done 10 days after the operation (Fig. 3). No vasospasm was observed on adjacent vessels. The patient was discharged without definite neurological deficits.

\section{Discussion}

Aneurysms of the vertebro-basilar system constitute $4 \%^{13)}$ to $10 \%^{14)}$ of all intracranial saccular aneurysms. The majority of these posterior circulation aneurysms arise at or near the basilar bifurcation, followed in order by those along the basilar trunk and on the vertebral artery at the posterior inferior cerebellar artery $(\mathrm{PICA})^{11) 14)}$. Aneurysms of the $\mathrm{PCA}$, on the other hand, are infrequent and estimated to comprise approximately $0.7 \%$ to $2.2 \%{ }^{6) 11) 13 \text { ) }}$ of all intracranial aneurysms, and approaximately 15\% 


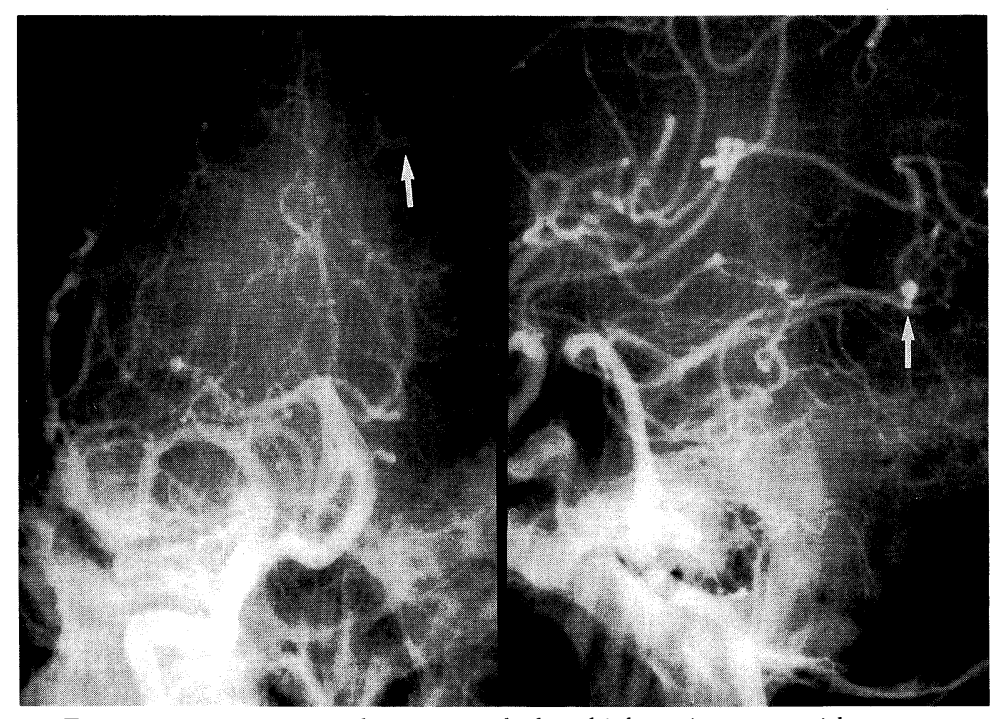

Fig. 2 Preoperative right retrograde brachial angiograms with anteroposterior (left) and lateral (right) views, demonstrating a saccular aneurysm (arrow) at the quadrigeminal segment of the left posterior cerebral artery.

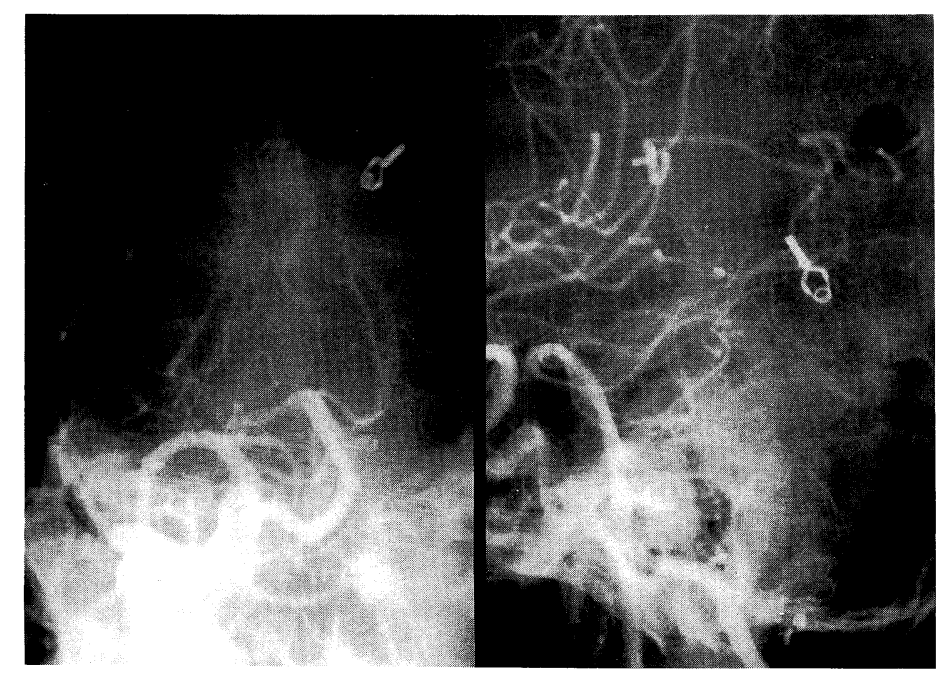

Fig. 3 Postoperative right retrograde brachial angiograms with anteroposterior (left) and lateral (right) views, showing the aneurysm completely obliterated with a Sugita's straight chip.

6)11)14) of the posterior circulation aneurysms. These PCA aneurysms tend to become giant and fusiform aneurysms 1)3)577)9)11), which may be treated by trapping ${ }^{14) 15)}$ or proximal clip occlusion ${ }^{2)}$ as alternative methods to neck clipping. According to the extensive review of the literature by Zeal and Rhoton ${ }^{16)}$, only $13 \%$ of all PCA aneurysms arise distal to the junction of the posterior temporal artery. In addition in his series of 97 cases with vertebro-basilar aneurysms, Yasargil ${ }^{14)}$ had only $3(3.1 \%)$ of distal PCA aneurysms which arose from the $\mathrm{P}_{3}$ segment of the PCA. Simpson and Parker ${ }^{12)}$ documented that as of 1986 there were only 21 cases of distal PCA aneurysms.

The aneurysm presented in this report can be classified as type $\mathrm{F}$ or $\mathrm{P}_{4}$ aneurysm according to Pia's ${ }^{11)}$ or Yasargil's ${ }^{14)}$ classification, respectively, on PCA aneurysm that arises on either the calcarine or 
Table 1 Clinical features in patients with distal PCA aneurysms

\begin{tabular}{|c|c|c|c|c|c|c|c|c|c|c|c|}
\hline \multirow{2}{*}{ Case } & \multirow{2}{*}{ Author } & \multirow{2}{*}{ (year) } & \multirow{2}{*}{ Age/sex - } & \multicolumn{2}{|c|}{ Aneurysm } & \multirow{2}{*}{$\begin{array}{l}\text { Clinical } \\
\text { presentation }\end{array}$} & \multirow{2}{*}{$\mathrm{CT}$} & \multicolumn{3}{|c|}{ Surgery } & \multirow{2}{*}{ Results } \\
\hline & & & & site & type & & & timing & approach & procedure & \\
\hline 1. & Obrador & (1967) & $20 / \mathrm{F}$ & $\mathrm{P} 3$ & giant & blindness & & & lobectomy & resection & \\
\hline 2. & Ishikawa & (1974) & $40 / \mathrm{M}$ & P3 & $\begin{array}{l}\text { saccular } \\
\text { bacterial }\end{array}$ & $\begin{array}{l}\mathrm{SAH} \\
\text { hemianopsia }\end{array}$ & & delayed & & resection & good \\
\hline 3. & Pia & (1977) & $43 / \mathrm{F}$ & $\mathrm{P} 4$ & saccular & $\begin{array}{l}\text { SAH } \\
\text { hemianopsia }\end{array}$ & & & lobectomy & clipping & \\
\hline 4. & Yasargil & (1984) & $45 / \mathrm{M}$ & P3 & $\begin{array}{l}\text { saccular } \\
\text { large }\end{array}$ & $\begin{array}{l}\text { SAH } \\
\text { hemianopsia }\end{array}$ & & delayed & OI & clipping & good \\
\hline 5. & Yasargil & (1984) & $46 / \mathrm{M}$ & $\mathrm{P} 3$ & saccular & $\mathrm{SAH}$ & & delayed & OI & clipping & good \\
\hline 6. & Yasargil & (1984) & $44 / \mathrm{M}$ & $\mathrm{P} 3$ & $\begin{array}{l}\text { saccular } \\
\text { large }\end{array}$ & $\begin{array}{l}\text { somnolence } \\
\text { hemiparesis } \\
\text { ataxia }\end{array}$ & & & OI & clipping & good \\
\hline 7. & Simpson & (1986) & $14 / \mathrm{F}$ & P3 & saccular & $\mathrm{SAH}$ & $\begin{array}{l}\text { SAH, ICH } \\
\text { IVH }\end{array}$ & early & ST & clipping & good \\
\hline 8. & Chang & (1986) & $43 / \mathrm{F}$ & $\mathrm{P} 3$ & saccular & $\mathrm{SAH}$ & & delayed & $\mathrm{ST}$ & clipping & fair \\
\hline 9. & Chang & (1986) & $63 / \mathrm{F}$ & $\mathrm{P} 3$ & saccular & $\mathrm{SAH}$ & & delayed & ST & clipping & good \\
\hline 10. & Nakao & (1988) & $57 / \mathrm{F}$ & P3 & saccular & $\mathrm{SAH}$ & $\begin{array}{l}\text { isodense } \\
\text { spot }\end{array}$ & & OI & clipping & \\
\hline 11. & Yoshinaga & (1989) & $35 / \mathrm{M}$ & $\mathrm{P} 3$ & saccular & $\begin{array}{l}\text { SAH } \\
\text { anisocoria } \\
\text { hemiparesis }\end{array}$ & $\mathrm{SAH}, \mathrm{ICH}$ & delayed & $\mathrm{ST}$ & trapping & fair \\
\hline 12. & Ogane & (1991) & $75 / \mathrm{F}$ & $\mathrm{P} 3$ & saccular & $\mathrm{SAH}$ & $\mathrm{SAH}$ & delayed & $\mathrm{ST}$ & clipping & fair \\
\hline 13. & Kikuchi & (1992) & $62 / \mathrm{F}$ & $\mathrm{P} 4$ & saccular & $\mathrm{SAH}$ & $\begin{array}{l}\text { SAH, ICH } \\
\text { IVH }\end{array}$ & early & OST & clipping & good \\
\hline
\end{tabular}

$\mathrm{OI}=$ occipital interhemispheric; ST= subtemporal; OST=occipital supratentorial; $\mathrm{SAH}=$ subarachnoid hemorrhage;

$\mathrm{ICH}=$ intracerebral hemorrhage; $\mathrm{IVH}=$ intraventricular hemorrhage

parieto-occipital artery. Thirteen cases, including our own, of such aneurysms that arose distal to the junction of the posterior temporal artery or the quadrigeminal segment of the PCA were found to have been reported in sufficient detail as to clinical presentation, neuroradiology, surgical procedure and results (Table 1). There were 5 men and 8 women, ranging in age from 14 to 75 years. Eleven cases had episodes of subarachnoid hemorrhage, and the remaining two cases had progressive neurological deterioration presumably due to mass effect of a large aneurysm. CT findings previously described in 4 patients ${ }^{810) 12) 15)}$ are characterized by subarachnoid blood clots present in the ambient and/or quadrigeminal cisterns occasionally associated with intracerebral hematomas involving the adjacent temporo-occipital region ${ }^{10) 15)}$. In addition in another patient intraventricular hemorrhage involving the lateral and third ventricles was demonstrated ${ }^{12)}$. These characteristic features are all well illustrated in the present case and clearly distinct from CT appear- ances by rupture of anterior circlation aneurysms. In rare instances the aneurysm itself was delineated as an isodense or hyperdense round lesion localized in the ambient cistern ${ }^{7) 8}$. As for surgical treatment the aneurysms were approached mostly in delayed operation through either subtemporal (5 cases) or occipital interhemispheric route (4 cases), and the majority of them underwent successful neck-clipping. The operative results were generally satisfactory in most cases. However, cerebral infarction occurred in two cases due to occlusion of the parent or adjacent artery after trapping or clipping procedures ${ }^{1) 10)}$.

Surgical approaches to this particular aneurysm of the PCA deserve special mention. Yasargil ${ }^{14)}$ subdivided these PCA aneurysms into four groups according to the location of the aneurysm; $\mathrm{P}_{1}, \mathrm{P}_{1} / \mathrm{P}_{2}$ junction, $\mathrm{P}_{2}$ and $\mathrm{P}_{3}$ aneurysms, and reviewed his surgical approaches based upon anatomical relationships. The surgical approach to aneurysms located in the proximal part of the PCA may be the pterional approach, or possiblly subtemporal 
approach. Pterional transsylvian approach may be best employed if the origin of the aneurysm is within $1 \mathrm{~cm}$ of the bifurcation of the basilar artery $\left(\mathrm{P}_{1}\right.$ and $\mathrm{P}_{1} / \mathrm{P}_{2}$ segments). By contrast for PCA aneurysms located distal to the junction of the posterior communicating artery ( $\mathrm{P}_{2}$ segment), a subtemporal approach may be utilized to allow easy access to the neck of the aneurysm. However, excessive retraction of the temporal lobe may result in intracerebral hematoma or cerebral edema ${ }^{2}$. In particular the presence of the well-developed vein of Labbé would eventually provide only a limited operative field to access to the PCA. For the more distal aneurysms $\left(\mathrm{P}_{3}\right.$ and $\mathrm{P}_{4}$ segemnts) such as the one in the present case, the approach of choice is either subtemporal or occipital approach. Yasargil ${ }^{14)}$ used occipital interhemispheric approach for $\mathrm{P}_{3}$ aneurysms in a sitting position with spinal drainage. Nakao et al. ${ }^{8)}$ also approached $\mathrm{P}_{3}$ aneurysm via occipital interhemispheric route with the patient placed in a lateral recumbent position, by which the occipital lobe of the affected side spontaneously sunk by its own weight and retraction of the occipital lobe could be kept minimal. However such surgical sequelae as visual field defect may ensue in this approach due to direct compression of the visual cortex or area striata on the medial surface of the occipital lobe ${ }^{8)}$. In the presented case the interhemispheric approach was abandoned because of the presece of multiple "bridging"veins between the superior sagittal sinus and the occipital lobe, and more distal location of the aneurysm than those documented by Yasargil ${ }^{14)}$ and Nakao ${ }^{8)}$. After ventricular drainage in a prone position, we took the occipital supratentorial approach, retracted the occipital pole, identified with ease the proximal portion of the PCA in the quadrigeminal cistern, and successfully clipped while retracting the occipital lobe superiorly from the tentorium. This approach combined with ventricular drainage was safe and feasible, especially for peripheral aneurysms of PCA as described in this report, offering excellent visualization for handling both the aneurysm and the associated intracerebral hematoma. This approach may also be designated as a "trans-occipital pole supratentorial approach". It should be emphasized again that surgical approach to the PCA aneurysms varies depending upon their anatomical locations.

\section{文献}

1) Chang HS, Fukushima T, Takakura $\mathrm{K}$, et al: Aneurysms of the posterior cerebral artery: Report of ten cases. Neurosurgery 19: 1006-1011, 1986

2) Drake CG, Amacher Aneurysms of the posterior cerebral artery. J Neurosurg 30: 468-474, 1969

3) Fukamachi $\mathrm{A}$, Hirato $\mathrm{M}$, Wakao $\mathrm{T}$, et al: Giant serpentine aneurysm of the posterior cerebral artery. Neurosurgery 11: 271-276, 1982

4) Ishikawa M, Waga S, Moritake K, Handa H: Cerebral bacterial aneurysms: Report of three cases. Surg Neurol 2: 257-261, 1974

5) Kondo $\mathrm{T}$, Higashi $\mathrm{H}$, et al: A case of giant aneurysm at the posterior cerebral artery. Neurol Surg(Tokyo) 6: 907911, 1978

6) Locksley HB: Report on the cooperative study of intracranial aneurysms and subarachnoid hemorrhage. Section V, Part I . Natural history of subarachnoid hemorrhage, intracranial aneurysms and arteriovenous malformation. Based on 6368 cases in the cooperative study. J Neurosurg 25: 219-239, 1966

7) Mochimatsu Y, Fujitsu K, Kuwabara T, et al: The zygomatic approach for posterior cerebral aneurysms. Surgery of Cerebral Stroke 15: 71-75, 1987

8) Nakao K, Yamada K, Hayakawa $T$, et al: Occipital approach for clipping of P3 aneurysm: Usefulness of lateral recumbent position with operating side down. Surgery for Cerebral Stroke 16: 317-320, 1988

9) Obrador S, Diessen G, Hernandez JR: Giant aneurysm of the posterior cerebral artery. Case report. J Neurosurg 26: 413-416, 1967

10) Ogane $\mathrm{K}$, Takahashi $\mathrm{T}$, Kimura $\mathrm{M}$, et al: $\mathrm{P} 3$ portion aneurysm of the posterir cerebral aretry: A case report. Neurol Surg (Tokyo) 19: 565-569, 1991

11) Pia HW, Fontana H: Aneurysms of the posterior cerebral artery. Locations and clinical pictures. Acta Neurochir (Wien) 38: 15-38, 1977

12) Simpson RK Jr, Parker WD: Distal posterior cerebral artery aneurysm. J Neurosurg 64: 669-672, 1986

13) Suzuki J, Hori S, Sakurai Y: Intracranial aneurysms in the neurosurgical clinics in Japan. J Neurosurg 35: 34-39, 1971

14) Yasargil MG: Microneurosurgery, Vol II, Stuttgart, New York, Georg Thime Verlag, 1984, pp 232

15) Yoshinaga $S$, Fukushima $T$, Hirakawa $T$, et al: Aneurysm at the PCA posterior temporal artery junction: A case report. Neurol Surg (Tokyo) 17: 1169-1173, 1989

16) Zeal AA, Rhoton AL: Microsurgical anatomy of the posterior cerebral artery. J Neurosurg 48: 534-559, 1978 